\title{
A Preliminary Study on the Reform of the Course of Engineering Practice Education in University
}

\author{
Yongming $\mathrm{Lu}$ \\ Engineering Practice Center of Tongji University \\ Shanghai, China 200092 \\ Huimin $\mathrm{Li}$ \\ Engineering Practice Center of Tongji University \\ Shanghai, China 200092
}

\author{
Xiaodong Ren \\ Engineering Practice Center of Tongji University \\ Shanghai, China 200092 \\ Lingqing Wang \\ Engineering Practice Center of Tongji University \\ Shanghai, China 200092
}

\begin{abstract}
Based on the teaching objectives of university engineering education, and rationally positioning the engineering practice education in universities, combined with the characteristics of the times and the common problems of engineering practice education in Universities in China at present stage, a curriculum reform plan of engineering practice education is put forward based on the principle of specialty.
\end{abstract}

Keywords-engineering practice; characteristics of the times; specialty oriented; curriculum reform

\section{INTRODUCTION}

The teaching goal of engineering education is to train students into engineering talents who meet the needs of society. Engineering talents should have the following characteristics:

1. With humanistic and social science literacy, a sense of social responsibility, professional ethics of engineering.

2. Have the related mathematical, natural science, and economy and management knowledge required for engineering work.

3. Have a systematic experiential learning experience in engineering, enhance the practical ability, and understand the frontier development status and trend of this major.

4. Have the ability to design and implement engineering experiment, and be able to analyze experimental results.

5. Master basic innovation methods, and have the attitude and consciousness of pursuing innovation; have the ability to design systems and processes by comprehensively using theory and technological means, and be able to consider the restriction factors including economy, environment, laws, safety, health and ethic in the design process.

Combined with the characteristics of engineering practice education, the positioning of engineering practice education in universities and colleges should reflect that the above engineering talents should equip with the Point 3 and Point 4 of the following characteristics, that is, the students in the disciplines related to engineering will be trained by the systematic engineering practice to improve the practical ability and to make the students understand the current situation and trend of the advanced development of the major, and students will be trained on basic innovation methods to cultivate their awareness of innovation.

\section{ENGINEERING'S TIME CHARACTERISTICS}

The content of engineering practice education should closely keep pace with the characteristics of the times. The characteristics of the times are embodied in two aspects: the features of modern processing and manufacturing industry and innovative social environment. In addition to the traditional processing means including lathing, clamping, milling, planning, grinding, heat treatment, casting and welding, modern processing and manufacturing enterprises have also added numerical control machining (computer numerical control turning, computer numerical control milling and machining centre), non-traditional machining (electrosparking, wire-electrode cutting and laser processing), rapid prototyping and other processing means. Under such circumstances, in line with the principle of systematic engineering practice education, the type of work project should be as systematic as possible when the practical training of the type of work is carried out. This kind of "system" lies in many types rather than varieties. The traditional machining, numerical control machining, feature machining and other types will be trained, not each type of work. Responding to the call of country's mass entrepreneurship and innovation, government at all levels and colleges and universities actively advocate innovation, and provide conditions for venues and funds. In the meantime, the Maker Movement, springing up at abroad, is gradually introduced into China. As is known to all, some district governments and streets in Shanghai have also established their own Maker space. All these provide a powerful external environment for engineering practice training to conduct Maker Education, train innovation method and cultivate students' awareness of innovation. 


\section{The COMMON PROBLEMS OF ChINA's ENGINEERING Practice EduCATION AT THE PRESENT Stage}

Most teachers in engineer practice education in China are workers of school-run factory. Therefore, there exist problems such as low level of education, backward scientific research capabilities, single teaching method and lagging teaching means. In addition, as some teachers retire, it is difficult for some types of work to recruit and some jobs may be "closed". The newly recruited teachers have limited technical descriptions. They can only perform teaching from the perspective of engineering science, while their engineering technology is relatively weak, which is detrimental to students to improve their "operational ability". Through the visit to Tsinghua University, Beijing Institute of Technology and other universities, they are all faced with this problem.

There are two main problems in the curriculum of engineering practice education:

Firstly, the course basically follows the principle of "many and complete types of work" so that the students can receive as much job education as possible. However, under the circumstance that the total time of engineering practice education does not change, the course time for all types of work is relatively little, and students can only understand little, and even they do not have time for hands-on practice. Teachers can only give a "score for their attitude" when conducting assessment for the corresponding type of work, which is far from the positioning of "improving the hands-on ability" in the engineering practice education of the university.

Secondly, in light of the characteristics of the major, all majors can be divided into three categories, namely, mechanical majors, near-mechanical majors and nonmechanical majors, and the class period is 256 hours, 128 hours and 64 hours respectively in "Table I".

TABLE I. ClassificAtion TABle of EngineEring Practice EDUCATION MAJOR OF TONGJI UNIVERSITY

\begin{tabular}{|c|l|}
\hline Mechanical & $\begin{array}{l}\text { All majors in School of Mechanical and Power, all } \\
\text { majors in College of Automotive Studies, and } \\
\text { mechanical majors in Sino-Italian Campus }\end{array}$ \\
\hline $\begin{array}{c}\text { Near- } \\
\text { Mechanical }\end{array}$ & $\begin{array}{l}\text { Mechanical majors in Sino-German College Applied } \\
\text { Sciences of Tongji University, and all majors in School } \\
\text { of Aerospace Engineering and Applied Mechanics }\end{array}$ \\
\hline \multirow{3}{\text{Non-}}{$\begin{array}{l}\text { All majors in College of Civil Engineering, all majors in } \\
\text { Mechanical }\end{array}$} & $\begin{array}{l}\text { College of Design and Innovation, all majors in School } \\
\text { of Ocean and Earth Science and College of Electrics and } \\
\text { Information Engineering, all majors in School of }\end{array}$ \\
Materials Science and Engineering, and logistics \\
management major in School of Economics \& \\
Management
\end{tabular}

Then, the engineering practice education plan is formulated by category, and the educational plan of the same type of majors is exactly the same. There is a clear defect in this classification, that is, we can neither carry out engineering practice education combined with the characteristics of major nor "teach students in accordance of their aptitude". For example, the Civil Engineering major should obviously focus on the types of work that are often used in the fields of civil engineering such as welding and casting, and the College of Design and Innovation majors should put more emphasis on the types of work that take non-metallic cutting and 3D printing as innovative tools.

\section{IDEAS OF CURRICULUM REFORM}

In terms of the curriculum reform, we should first aim at the positioning of engineering practice education: the students in the disciplines related to engineering will be trained by the systematic engineering practice to improve the practical ability and to make the students understand the current situation and trend of the advanced development of the major, and students will be trained on basic innovation methods to cultivate their awareness of innovation. The system here means that the type of work project should be as systematic as possible when practical training of the type of work is carried out. This kind of "system" lies in many types rather than varieties. The traditional machining, numerical control machining, feature machining and other types will be trained, not each type of work. Moreover, it is necessary to increase the content of Maker Education to adapt to the characteristics of the times.

Engineering practice center of Tongji University currently adopts the $1+1$ education model, namely, the type of work education, and innovative production education. The type of work education adopts work-shift teaching, and there are a total of 17 types of work, which are turner, fitter, miller, grinder, casting, heat treatment, welding, computer numerical control lathe, machining center, wire-electrode cutting, nonmetal cutting, 3D printing, PAC control, laser-microengraving, green energy resource and pneumatic fluid power. Innovative production education cannot carry out work shift, instead, special teachers instruct students to conduct innovative production. According to the situation to prepare process route, the teachers in corresponding jobs lead students to process the corresponding parts, and then the students shall assemble and debug then by themselves.

\section{A. The Large and Small Types of Work}

The large type of work refers to the intensified type of work. Students in all majors are required to practice, and the course setting of large type of work is relatively perfect, and the class hour extends to ensure sufficient training time, and its aim is to improve students' operational ability. There are rigorous standards for assessment, and the contents of various assessments are refined. Small type of work refers to cognitive work, with a shorter class hour. The course content only involves the teacher's introduction to the work type and the teacher's operation on the corresponding device, and the students do not operate on the machine.

\section{B. Turner and Fitter Belong to the Large Type of Work of All Engineering Practice Majors}

The fitter is the foundation of machinery, and all equipment and tools used are relatively simple, such as file, hand saw, steel ruler, height gauge, hammer and so on. However, they are the earliest tools that humans have used since they entered the era of mechanical manufacturing, and they are easy for students to understand the traditional mechanical manufacturing from the perspective of "original source", which is an indispensable part of the students' 
concept of "system machinery". Until now, fitters have become an indispensable part of modern manufacturing enterprises. Fitter training mainly focuses on manual operation, characterized by intense labor, strong operational ability and strong labor awareness, which can cultivate students' good working habits and awareness and enhance their labor skills.

As one of the traditional machining methods, the lather can turn out the solid of revolution with respect to the milling machine, planer, grinding machine, heat treatment, casting and welding. The curving effect caused by parts is not available in other traditional types of work, which can arouse students' interest. The lathe functions are relatively strong, including lathe taper, tapping, centre bore drilling and knurling

\section{For Different Majors, Individual Types of Work Can Be Flexibly Divided into Large and Small Types of Work}

Different types of work have different relationship with various majors, so the large type of work and small type of work should be flexibly set based on major characteristics. For example, all majors of College of Design and Innovation should regard 3D printing as the large type of work, and all majors of College of Electronics and Information Engineering should divide PAC control into the large type of work.

Besides, all mechanical and near-mechanical majors regard $3 \mathrm{D}$ printing as the large type of work. There are two main reasons: first, as an emerging mechanical manufacturing technology, 3D printing is an advanced technology integrating machinery, materials, computers, control, CAD/CAM and other technologies. Because of its ability of rapid prototyping and complex model making, it has been extensively used in the industry. Second, the 3D printing technology itself is the product of innovation. Its application in the classroom can cultivate students' creative thinking, so that students can experience the sense of achievement brought by innovation in design and operation. Facing a printer, students can have infinite imaginary space and design any personalized model that fits their own ideas without considering restrictions of mechanical processing.

\section{The Hydraulic and Pneumatic Transmission Work Types Are Incorporated in PAC Control Work Type as New PAC Control Work Type}

Hydraulic and pneumatic transmission is a form of transmission that uses fluid as the working medium to transmit and control energy, and in essence it is a control technology. The green energy technology is a technology that converts clean energy such as wind energy and solar energy to the energy required for human production activities. We can also combine automatic control technology to achieve fullautomatic energy conversion. The two types of work are regarded as the practice content of PAC control, which can not only strengthen students' learning effect of PAC control work type, but also make the practical content of PAC control have more practical significance.

\section{E. The Types of Work with the Same Machining Characteristic Are Combined into A Large Type of Work}

1) The wire-electrode cutting, non-metal cutting and laser-micro-engraving are combined into a large type of work of nontraditional machining: The wire-electrode cutting adopts the principle of pulse spark discharge to remove metal, so as to achieve the purpose of cutting and cause no force on the workpiece during processing, so that all kinds of workpiece with complex shape and fine precision are processed. The non-metal cutting and laser-micro-engraving both utilize the characteristics of coherence, high directivity and high energy of the laser to process the workpiece. Combining wire-electrode cutting, non-metal cutting and laser-micro-engraving into a large type of work of nontraditional machining, the students are free to choose a type of work and combine the assignment of clinical teacher to carry out the corresponding practice on related work types.

2) The computer numerical control lathe, computer numerical control milling and machining centre are combine into a large type of work of computer numerical control machining: The computer numerical control lathe and computer numerical control milling are the processing machine tools, with computer numerical control programming functions, which are developed based on the ordinary lathe and milling. Functionally, there is no essential difference between the ordinary lathe and milling. The machining center is a five axis machine tool that is developed based on numerical control machine tool, which can realize the machining of any curved surface. All the computer numerical control lathe, computer numerical control milling and machining centre have numerical control function and need to be programmed when they are used. Therefore, the three types of work are combined into a large type of work of computer numerical control machining. The students are free to choose a type of work and combine the assignment of clinical teacher to carry out the corresponding practice on related work types.

\section{F. Establish An Experimental Area for Maker Training}

Compared with other secondary colleges, the greatest advantage of engineering practice education lies in engineering technology. With perfect processing equipment and strong mechanical processing teachers, students can better turn ideas into products, so the resources can be fully integrated to perform Maker Education for students.

\section{CURRICULUM REFORM PlaN}

In the educational model, the $1+1$ model is still continued, namely, work type education and maker education. All types of work will be integrated to form three teaching modules, namely, traditional machining module, numerical control machining module and nontraditional machining module. The traditional machining modules include seven types of work: turner, fitter, miller, grinder, casting, heat treatment, welding. The numerical control machining modules include three types of work: computer numerical control lathe, computer numerical control milling and machining center. The 
nontraditional machining modules include three types of work: wire-electrode cutting, non-metal cutting and laser-microengraving.

On the basis of the original innovation production, we will integrate innovation production, 3D printing and PAC control into a pilot area for Maker training. The innovation production, 3D printing and PAC control will be merged into a Maker training pilot area, which will be a place for Maker education to conduct specific maker education. Its biggest feature is to add the content of PAC control and 3D printing. The reasons are as follows: modern machining equipment is increasingly developing toward electromechanical integration. Various automatic products emerge in endlessly, and PAC is incorporated into this pilot area for theoretical education and practical guidance of PAC control. The great advantage that $3 \mathrm{D}$ printing has in rapid prototyping has been played in the R\&D of enterprise products. Students can quickly produce their models with the help of 3D printer to demonstrate product design plan.

\section{A. Plan for Work Type Education Course}

We still classify the majors into mechanical, nearmechanical, and non-mechanical categories according to major characteristics. The classification method is the same as those of table 1, so as to determine the class hour of engineering practice education.

1) Plan for non-mechanical courses: The major characteristics of College of Design and Innovation emphasize product design, industrial design and environmental design, so 3D printing is regarded as a large type of work. On the one hand, improve their ability to use 3D printers and to perform simple troubleshooting. On the other hand, we can flexibly adjust the model's printing scheme based on the characteristics of the 3D printer to make students better prototype the model. The major characteristics of College of Civil Engineering highlight civil engineering, geological engineering, and port channel and coastal engineering, so welding is regarded as a large type of work. The major of School of Physics Science and Engineering stresses photoelectric information science and engineering, so the PAC control is regarded as a large type of work. The major of College of Electronics and Information Engineering focuses on electronic information engineering, electric engineering and its automation, automation, electronic science and technology, so the PAC control is regarded as a large type of work. The major of School of Materials Science and Engineering puts emphasis on changes in the microstructure of the materials, so the heat treatment is regarded as a large type of work. The major of School of Ocean and Earth Science emphasizes geology, geophysics and development of marine resources, and is not closely connected to mechanical processing technology, so 3D printing is regarded as a large type of work considering the innovative features of 3D. All majors of School of Economics and Management focus on project management, information management, and logistics management, and are not closely connected with the machining technology, so 3D printing is regarded as a large type of work considering the innovative features of 3D. Specific course programs are shown in "Table II".

TABLE II. COURSE Schedule of All Non-Mechanical MaJors

\begin{tabular}{|c|c|c|c|c|c|c|c|}
\hline $\begin{array}{l}\text { Majors } \\
\text { Types } \\
\text { of Work }\end{array}$ & $\begin{array}{l}\text { All Majors } \\
\text { in College } \\
\text { of Civil } \\
\text { Engineering }\end{array}$ & $\begin{array}{l}\text { All Majors } \\
\text { in School of } \\
\text { Physics } \\
\text { Science and } \\
\text { Engineering }\end{array}$ & $\begin{array}{c}\text { All Majors } \\
\text { in College } \\
\text { of Design } \\
\text { and } \\
\text { Innovation }\end{array}$ & $\begin{array}{l}\text { All Majors } \\
\text { in School of } \\
\text { Ocean and } \\
\text { Earth } \\
\text { Science }\end{array}$ & $\begin{array}{l}\text { All Majors } \\
\text { in College } \\
\text { of Electrics } \\
\text { and } \\
\text { Information } \\
\text { Engineering }\end{array}$ & $\begin{array}{l}\text { All Majors } \\
\text { in School of } \\
\text { Materials } \\
\text { Science and } \\
\text { Engineering }\end{array}$ & $\begin{array}{l}\text { All Majors in School of } \\
\text { Economics \& } \\
\text { Management }\end{array}$ \\
\hline Turner & 8 & 8 & 8 & 8 & 8 & 8 & 8 \\
\hline Fitter & 8 & 8 & 8 & 8 & 8 & 8 & 8 \\
\hline Miller & 4 & 4 & 4 & 4 & 4 & 4 & 4 \\
\hline Grinder & 4 & 4 & 4 & 4 & 4 & 4 & 4 \\
\hline Molder & 4 & 4 & 4 & 4 & 4 & 4 & 4 \\
\hline $\begin{array}{l}\text { Heat } \\
\text { treatment }\end{array}$ & 4 & 4 & 4 & 4 & 4 & 8 & 4 \\
\hline Welding & 8 & 4 & 4 & 4 & 4 & 4 & 4 \\
\hline $\begin{array}{l}\text { Numerical } \\
\text { control } \\
\text { machining }\end{array}$ & 8 & 8 & 8 & 8 & 8 & 8 & 8 \\
\hline $\begin{array}{l}\text { Nontradition } \\
\text { al machining }\end{array}$ & 8 & 8 & 8 & 8 & 8 & 8 & 8 \\
\hline 3D printing & 4 & 4 & 8 & 8 & 4 & 4 & 8 \\
\hline PAC control & 4 & 8 & 4 & 4 & 8 & 4 & 4 \\
\hline $\begin{array}{ll}\text { Total class } \\
\text { hours }\end{array}$ & 64 & 64 & 64 & 64 & 64 & 64 & 64 \\
\hline
\end{tabular}

2) Plan for near-mechanical courses: The major of mechanical \&electronic engineering, and major of building electrical and intelligent in Sino-German College Applied Sciences of Tongji University focus on the control, so the two majors in Sino-German College Applied Sciences of Tongji
University regard PAC control as a large type of work. Combined with green energy and pneumatic fluid transmission work type, we will apply PAC control technology to the practice link of the above two types of work. The flight vehicle manufacturing major and engineering 
mechanics major in School of Aerospace Engineering and Applied Mechanics do not obviously emphasize a certain type of work, so the content of large type of work will be strengthened.

The total class time for mechanical majors is 128 hours, and the specific course plan is shown in "Table III".

TABLE III. COURSE Schedule of All NeAR-Mechanical Majors

\begin{tabular}{|l|l|l|}
\hline $\begin{array}{l}\text { Majors } \\
\begin{array}{l}\text { Types } \\
\text { of Work }\end{array}\end{array}$ & $\begin{array}{c}\text { All Majors in Sino-German } \\
\text { College Applied Sciences of } \\
\text { Tongji University }\end{array}$ & $\begin{array}{c}\text { All Majors in } \\
\text { School of } \\
\text { Aerospace } \\
\text { Engineering and } \\
\text { Applied Mechanics }\end{array}$ \\
\hline Turner & 20 & 20 \\
\hline Fitter & 16 & 20 \\
\hline Miller & 4 & 4 \\
\hline Grinder & 4 & 4 \\
\hline Molder & 4 & 4 \\
\hline $\begin{array}{l}\text { Heat } \\
\text { treatment }\end{array}$ & 4 & 4 \\
\hline Welding & 4 & 4 \\
\hline $\begin{array}{l}\text { Numerical } \\
\text { control } \\
\text { machining }\end{array}$ & 20 & 20 \\
\hline $\begin{array}{l}\text { Nontradition } \\
\text { al machining }\end{array}$ & 16 & 20 \\
\hline 3D printing & 16 & 20 \\
\hline PAC control & 20 & 8 \\
\hline $\begin{array}{l}\text { Total class } \\
\text { hours }\end{array}$ & 128 & 128 \\
\hline
\end{tabular}

3) Plan for mechanical courses: The major in School of Mechanical and Power Engineering focuses on mechanical design and manufacturing and its automation and energy environment, so PAC, heat treatment and welding will be regarded as a large type of work for key education. Considering the more welding technology used in the automobile surface, and the importance of the development direction of new energy vehicle and its casting to auto parts, the automotive engineering major in College of Automotive Studies regards welding, PAC control and casting as a large type of work for key education. The total class time for nearmechanical majors is 256 hours, and the specific course plan is shown in "Table IV".
Table IV. Course Schedule of All Mechanical Majors

\begin{tabular}{|c|c|c|c|}
\hline $\begin{array}{l}\text { Majors } \\
\text { Types } \\
\text { of Work }\end{array}$ & $\begin{array}{c}\text { Mechanical } \\
\text { Design } \\
\text { Manufacture and } \\
\text { Automation } \\
\text { Major in } \\
\text { School of } \\
\text { Mechanical and } \\
\text { Power } \\
\text { Engineering }\end{array}$ & $\begin{array}{c}\text { Construction } \\
\text { Environment and } \\
\text { Energy } \\
\text { Application } \\
\text { Engineering } \\
\text { Major in } \\
\text { School of } \\
\text { Mechanical and } \\
\text { Power } \\
\text { Engineering }\end{array}$ & $\begin{array}{c}\text { Automotiv } \\
\text { e } \\
\text { Engineerin } \\
\text { g Major in } \\
\text { College of } \\
\text { Automotiv } \\
\text { e Studies }\end{array}$ \\
\hline Turner & 32 & 32 & 32 \\
\hline Fitter & 32 & 32 & 32 \\
\hline Miller & 16 & 8 & 8 \\
\hline Grinder & 8 & 8 & 8 \\
\hline Molder & 16 & 8 & 24 \\
\hline Heat treatment & 16 & 16 & 8 \\
\hline Welding & 8 & 24 & 16 \\
\hline $\begin{array}{l}\text { Numerical } \\
\text { control } \\
\text { machining }\end{array}$ & 32 & 32 & 32 \\
\hline $\begin{array}{l}\text { Nontraditional } \\
\text { machining }\end{array}$ & 32 & 32 & 32 \\
\hline 3D printing & 32 & 32 & 32 \\
\hline PAC control & 32 & 32 & 32 \\
\hline Total class hours & 256 & 256 & 256 \\
\hline
\end{tabular}

\section{B. Curriculum Scheme of Maker Education}

For all the students who need to carry out engineering practice education, they can take Maker education as an elective course at the beginning of each semester, and the number should be controlled within $5 \%$ of the total students, and the students who successfully select the course will not carry out the content of types of work education. The students who successfully select the course will firstly receive the training of professional innovative method (TRIZ), and then the adviser of $3 \mathrm{D}$ printing and PAC control explain the corresponding theory of types of work. Finally, the students should form a three-people group to cooperate and design the work and guided by the adviser of innovative approach, 3D printing and PAC control to complete the final design and making for the project.

\section{CONCLUSION}

In the new curriculum scheme, different types of work may be flexibly converted into large and small types of work according to the various majors of students, which needs the students to design various teaching schemes to adapt different teaching depth and teaching effect; after several types of work are combined, the corresponding advisers need to master more skills of types of work. One the one hand, the increase of teacher's skills helps them to have more comprehensive understanding for the content of types of work; one the other hand, it makes up for the shortage of teacher resources. The curriculum is closer to the professional needs of students, which is conducive to the future development of students and also is the greatest significance of curriculum reform. 


\section{REFERENCES}

[1] Edward, F.Crawley, Zha Jianzhong, et al. On Engineering Education Environment $[\mathrm{J}]$. Research in Higher Education of Engineering, 2008(4):13-21. Edward, F.Crawley, 查建中, 等. 工程教育的环境[J]. 高 等工程教育研究, 2008(4):13-21.

[2] Wang Gang. Interpretation and Thinking of CDIO Engineering Education Model [J]. China High Education Research, 2009(5):86-87. 王刚. CDIO 工程教育模式的解读与思考 [J]. 中国高教研究, 2009(5):86-87.

[3] Gu Binglin. Reformation and Development of Higher Engineering Education in China [J]. Research in Higher Education of Engineering, 2004(5):5-8. 顾秉林. 中国高等工程教育的改革与发展 [J]. 高等工程 教育研究, 2004(5):5-8.

[4] Liu Jizhen. Curriculum reform: A View from Engineering [J]. Research in Higher Education of Engineering, 2006(4):42-45. 刘吉筛. 工程教育 课程改革的思维转向:工程化的视角 [J]. 高等工程教育研究, 2006(4):42-45.

[5] Gu Binglin. Three Problems to Be Solved Urgently in Engineering Education [J]. China Higher Education, 2002(22):9-11. 顾秉林. 工程教 育中亟待解决的三个问题 [J]. 中国高等教育, 2002(22):9-11.

[6] Li Zheng, Lin Feng. On the Development Trend of Engineering Education from the Nature of Engineering [J]. Research in Higher Education of Engineering, 2007(2):19-25. 李正, 林凤. 从工程的本质 看工程教育的发展趋势[J]. 高等工程教育研究, 2007(2):19-25.

[7] Zhu Gaofeng. Innovation and Engineering Education_-Preliminary Discussion on the Requirements for Higher Engineering Education in Building Innovative Countries [J]. Research in Higher Education of Engineering, 2007(1):1-5. 朱高峰. 创新与工程教育—初议建立创 新型国家对高等工程教育的要求[J]. 高等工程教育研究, 2007(1):1-5.

[8] Li Peigen. Engineering Education Needs a Large Scale Engineering [J]. Research in Higher Education of Engineering, 2011(3):1-3. 李培根. 工 程教育需要大工程观[J]. 高等工程教育研究, 2011(3):1-3.

[9] Sun Kangning, Fu Shuigen, Liang Yande, et al. Discussion on Problems, Countermeasures and General Education Attributes in Engineering Practice Education [J]. China University Teaching, 2011(9):17-20. 孙康 宁, 傅水根, 梁延德, 等. 浅论工程实践教育中的问题、对策及通识教 育属性[J]. 中国大学教学, 2011(9):17-20.

[10] Fu Shuigen, Zhang Xuezheng, Yan Shaohua, et al. Discussion on the Creativity Training in Different Levels in Engineering Practical Education [J]. Research On Education Tsinghua University, 2001, 22(3):170-172. 傅水根, 张学政, 严绍华, 等. 工程实践教学中分层次开 展创新教育的探讨 [J]. 清华大学教育研究, 2001, 22(3):170-172.

[11] Fu Shuigen. Review and Prospect of the History of Higher Engineering Practice Education in China [J]. Experimental Technology and Management, 2011, 28(2):1-4. 傅水根. 我国高等工程实践教育的历史 回顾与展望 $[\mathrm{J}]$. 实验技术与管理, 2011, 28(2):1-4.

[12] Fu Shuigen. Exploration of Engineering Practice Education: Exploration of engineering practice education. Vol. $2[\mathrm{M}]$. Tsinghua University Press, 2013. 傅水根. 探索工程实践教育: Exploration of engineering practice education. 第 2 辑[M]. 清华大学出版社, 2013. 